\title{
The Influence of Self-Efficacy and Work Environment on Employee Performance: Empirical Study on PT Sarana Indoguna Lestari Surabaya
}

\author{
Paolo Rossi L. Ambarita*, Agustina Hanafi, Yuliani \\ Postgraduate Program, Sriwijaya University, Palembang, Indonesia \\ Email: *paololiberato89@gmail.com
}

How to cite this paper: Ambarita, P. R. L., Hanafi, A., \& Yuliani (2022). The Influence of Self-Efficacy and Work Environment on Employee Performance: Empirical Study on PT Sarana Indoguna Lestari Surabaya. Open Journal of Business and Management, 10, 263-280.

https://doi.org/10.4236/ojbm.2022.101016

Received: October 22, 2021

Accepted: January 14, 2022

Published: January 17, 2022

Copyright $\odot 2022$ by author(s) and Scientific Research Publishing Inc. This work is licensed under the Creative Commons Attribution International License (CC BY 4.0).

http://creativecommons.org/licenses/by/4.0/

\begin{abstract}
The purpose of this study is to determine empirical evidence of the effect of the influence of self-efficacy and work environment on employee performance with motivation as an intervening variable in an empirical study of employees of PT Sarana Indoguna Lestari Surabaya. This research is causal in nature, and uses primary data of 135 respondents with purposive sampling technique. Amos's Structural Equation Modeling (SEM) analysis program was used to measure the relationship between research variables. The results showed that Self-efficacy does not have a significant effect on performance, while the work environment has a significant effect on performance and the motivation variable is able to mediate Self-efficacy and work environment on performance, so that it has a significant positive effect on performance.
\end{abstract}

\section{Keywords}

Self-Efficacy, Work Environment, Performance

\section{Introduction}

Human resources, within an industry, are the company's spearhead in attaining its objectives. The most important aspect for the industry to pay attention to is the employee performance due to its significant impact on the company's growth and development (Diamantidis \& Chatzoglou, 2019). According to Robbins \& Coulter (2012), employee performance is the outcome of a person's work quality and quantity in carrying out duties according to the responsibilities assigned. In general, employee performance is impacted by three variables: firstly is the factor inside the employee which is the self-efficacy (Redifer et al., 2021), se- 
condly is the factor in the firm's work environment (Palvalin, 2019), and thirdly is the influence from outside the company (Diamantidis \& Chatzoglou, 2019).

Self-efficacy is a term in social cognition theory that relates with an individual's belief in his capacity to do the tasks that have been assigned by their supervisor (Li, 2020). Meanwhile, a work environment is a workplace where all employees of an organisation firm work together with a variety of supporting facilities to achieve some goals in accordance with the company's vision and mission (Palvalin, 2019). A workplace environment indirectly influences employee satisfaction and then encourages them to more productively work (Mone \& London, 2018; Nguyen et al., 2015). Moreover, Cherian and Jacob (2013) stated that employee performance in a firm organization is influenced by some key factors, such as employee self-efficacy, work environment, and work motivation.

PT Indoguna Utama is one of the numerous multinational food and beverage companies operating in Indonesia. Based on the internal data assessed, it shows that the company continues to have issues with employee performance, ranging from the issue of not following the company's standard operating procedures (SOP) appropriately, indisciplinary action, and even existence of conflict between employee and customer which is clearly detrimental to the company. Certainly those issues are potential to harm the company's reputation among customers. In this study, Table 1 summarises some SOP mistakes and other incidents that have happened in the last five years in the company.

Based on Table 1, it can be seen that employee violations against standard operating procedures, undisciplined behavior and conflicts with consumers still occur at PT. Indoguna Lestari Surabaya. This illustrates that the work rules procedures in the company's organization are still not optimally obeyed by all employees. This condition shows the urgency to investigate the determinants of employee performance in order to assess the causes of violations that still occur in the company's organization. Several indicators that can be used as measuring values for employee performance include self-efficacy, work environment, and employee motivation. Assessment of the role of employee self-efficacy and work environment on employee motivation is considered important to be taken into account to assess the impact of the work environment and employee self-efficacy

Table 1. Recapitulation of employee assessment in PT Sarana Indoguna Lestari, 2016-2020.

\begin{tabular}{lccccccc}
\hline \multirow{2}{*}{ Problems } & \multicolumn{3}{c}{ Number of Cases } & \multicolumn{2}{c}{ Total } \\
\cline { 2 - 7 } & 2016 & 2017 & 2018 & 2019 & 2020 & \\
\hline 1. Standard Operating Procedure (SOP) Errors & 1 & 5 & 1 & 3 & 1 & 11 \\
2. Indisciplinary Action & 1 & - & 2 & 2 & 1 & 6 \\
3. Conflict with Customer & & & 1 & & 1 & 2 \\
\multicolumn{1}{c}{ Total Cases } & 2 & 5 & 4 & 5 & 3 & 19 \\
\hline
\end{tabular}

Source: Employee coaching recapitulation (2020). 
on employee motivation. While the direct and indirect relationship of the work environment and employee self-efficacy on employee performance is considered a source of reference that shows how the role of motivation in mediating the relationship between the work environment and employee self-efficacy with employee performance at PT. Indoguna Lestari Surabaya.

\section{Literature Review}

\subsection{The Influence of Self-Efficacy on Performance}

The first researcher that developed the self-efficacy concept in order to understand human ability and performance is Bandura (1982, 2012). He defined self-efficacy as a person's belief to be successfully performing any duties that task to individual person. The basic theory of self-efficacy explains human motivation and ambition possesses to achieve personal accomplishment through sustainable performance improvement. It is because when they believe that they are capable to achieve the best results, hence they act or insist on their efforts although they should face problems and difficulties (Pajares \& Miller, 1994). Lunenburg (2011) in his research defined self-efficacy as people's ability to solve particular tasks that they prefer to learn and appropriate with their goals. Based on statements from these experts we can that self-efficacy has a particular impact that influences human performance and their occupation.

Self-efficacy depends on personal assessments against their own experiences and past performance (Bandura, 2012) which indirectly contributes to an individual's thought toward their ability to solve regular and special tasks (Coutinho, 2008). Self-efficacy refers to increasing the performance and self-confidence of employees, where who have high self-efficacy will perform any task with high confidence (Tierney \& Farmer, 2011). Furthermore, Nugraha \& Jabeen (2020) stated that a person's belief in the quality of his abilities is related to self-efficacy factors and indirectly encourages their future career development. Several studies have been revealed that self-efficacy significantly contributes a positive effect on an individual's performance improvement (Schmidt \& DeShon, 2010; Van Dijk \& Kluger, 2011). On the other hand, there are also experiments that demonstrated a negative effect of self-efficacy were conducted in laboratory settings, where no salient reward and compensation offered by firms (Vancouver et al., 2014).

\subsection{The Influence of Work Environment on Performance}

The work environment is divided into a physical environment and a virtual environment. The physical environment is all the rooms in the workplace or office including tables, chairs, and any furniture in the office (Palvalin, 2019). In an effective physical environment, knowledge workers are able to concentrate on their tasks (Maarleveld et al., 2009). Meanwhile, the virtual environment is any technology tool that uses for everything related to communication and information (Palvalin et al., 2013). Study by Narasuci et al. (2018) found that the physi- 
cal work environment and good working relationships between good colleagues and superiors can improve performance both directly and indirectly. Cui et al. (2013) in their study found evidence that office air temperature motivates employee satisfaction and performance for a case in China.

In England, Jayaweera (2015) used a survey questionnaire involving $254 \mathrm{em}$ ployees on 25 hotels in Bristol and found that the work environment motivates and improves employee performance in the hotel sector. Malik et al. (2011) studied this case in Pakistan and revealed work environment influences an individual's ability to work competently, safely and appropriately with operational performance procedures. Further, Nguyen et al. (2015) investigated the role of work environment toward employee performance in Vietnam, both in the government and private sectors. Their study found that work environment is one of key factors that increase the satisfaction and performance of employeess. Based on those studies, it can be assumed that a condition of work environment, both physically and non-physically, has a sustainable impact on employee performance.

\subsection{The Influence of Work Motivation on Performance}

Diamantidis and Chatzoglou (2019) stated that improving performance can be influenced by employee work motivation in carrying out their duties and responsibilities. Motivation is a behavioural impulse that motivates a person's thinking power to carry out an activity (Kreitner et al., 2001). Motivation can also be interpreted as a person's desire or obsession with the desire to achieve maximum results from what he wants or does (Mathis \& Jackson, 2006). Meanwhile, Khan (2012) describes motivation as a person's desire or hope for an activity that he considers to be beneficial for him. Meanwhile, Efendi et al. (2020) defined work motivation as an encouragement given by a company to its employees to be more productive and maximal in carrying out their work responsibilities.

Study by Pangastuti et al. (2020) found that work motivation and compensation significantly encouraged the performance of SME's employees that working on batik business in Yogyakarta City. Research conducted by Shahzadi et al. (2014) found that work motivation has a positive and significant effect on employee performance. The results of the research by Zameer et al. (2014) found work motivation has a positive and significant effect on employee performance. The results of the same research conducted by Bayramoğlu et al. (2013) also found that a positive and significant effect of work motivation on employee performance. While research Adeoye (2019) found that work motivation has a weak and insignificant influence on employee performance.

\subsection{The Influence of Self-Efficacy on Motivation}

Any impact on an employee's commitment to her career is found to be associated with his ability to link his motivation to her performance levels and an 
antecedent to this motivation is his self-efficacy (Morrow, 1993). Any individual who has the ability to show commitment to his career always is found to make an attempt to improve his skills and motivate himself to perform well. Previous studies have shown that both self efficacy and motivation are both integral part of performance and both these factors contribute to a good service quality, effectiveness and efficiency in the workplace (Cherian \& Jacob, 2013). The study by Day and Allen (2004) analysed the impacts of motivation and self-efficacy in improving the work related performance of the employees.

Self-efficacy, intrinsic motivation and job satisfaction were factors that was studied by Olusola (2011) in order to investigate their influence on industrial workers performance in order to discover a way to increase employees' productivity in Nigerian industrial settings. The research study's results indicated two things. The first identified that self-efficacy, intrinsic motivation and job satisfaction will predict the job performance of industrial workers. The second presented the idea that each of these variables will predict the job performance of workers. Hasyim (2018) states that Self Efficacy has a significant effect on the motivational aspect. This is in line with Cherian and Jacob (2013) which states that the role of self-efficacy is needed by individuals in motivating themselves to be able to complete assignments well. According to Nugraha and Jabeen (2020) states that self-efficacy is a person's belief in his ability to be able to carry out tasks well.

\subsection{The Influence of Work Environment on Motivation}

Based on research by Narasuci, Setiawan, \& Noermijati (2018) found that the increase in performance motivation is influenced by the work environment, especially with a safe, comfortable and conducive work environment to increase morale. This is in accordance with Hughes et al. (2020) which states that a good work environment will make someone feel comfortable at work and motivated to complete tasks. A study by Andrianto and Siringoringo (2020) found that motivation depends on how comfortable employees are at work and how the work environment and company support their activities. Work environment social support factors may enhance trainee self-efficacy, promote a learning goal orientation, and increase motivation (Khan, 2012), which in turn can result in desired outcomes including improved productivity, job satisfaction, and a higher likelihood of using optimal skills on the job (Kurtessis et al., 2017). Social support mechanisms within the work environment strongly motivate employees to optimally their performance. Furthermore, the work environment factor can increase motivation and promote learning goal orientation for employees to better understand the company's goals (Nguyen et al., 2015), which in turn can encourage productivity, increase employee satisfaction, and accelerate company to achieve their goals (Malik et al., 2011). Most empirical evidence also shows how the work environment support mechanism is able to stimulate employee motivation to more optimally provide their effort and capability for the company 
(Jayaweera, 2015).

\subsection{Research Framework and Hypotheses}

Based on theory and empirical evidences that were previously discussed, we then develop research framework and determine hypotheses as in Figure 1.

Research hypotheses:

H1: Self-efficacy has significant influence on employee performance.

$\mathrm{H} 2$ : Work environment has significant influence on employee performance.

H3: Self-efficacy has significant influence on motivation.

$\mathrm{H} 4$ : Work environment has significant influence on motivation.

H5: Motivation has significant influence on employee performance.

H6: Self-efficacy has significant influence on employee performance by the existence of motivation.

H7: Work environment has significant influence on employee performance by the existence of motivation.

\section{Methodology}

This study is categorized as an explanation study. According to Widiyanti et al. (2020), Explanatory study is the study that tries to understand the connections between variables or how one variable influences other variables. In this research, quantitative and qualitative data types are employed in the investigation. Quantitative data is data in the form of numbers or the qualitative data that is numbered, whereas qualitative data is data in the form of words, schemes, and drawings. Primary and secondary data sources are the two types of data sources used in this research. Primary data, such as the results of questionnaires issued, and secondary data, such as a summary of performance assessments received from the company's management, are utilized as the sources of data in this research. A population is a group or collection of people, events, or interesting objects in which the related researcher wishes to form an opinion based on statistical data (Sekaran \& Bougie, 2010).

The workers actively working at PT Sarana Indoguna Lestari Surabaya in 2020

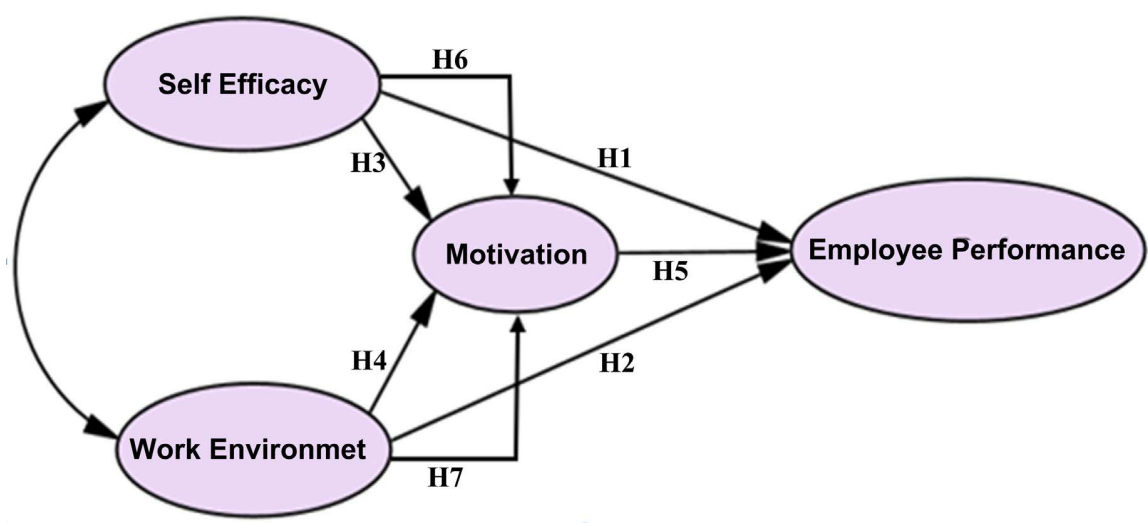

Figure 1. Research framework. 
have a total number of over 200 employees, according to the survey in this reseach. In quantitative research, sample is a subset of the population's size and characteristics. The samples taken must be really the representative of the research population (Sekaran \& Bougie, 2010). The samples used in this research are based on criterion suggested by Hair et al. (2013) with research technique approach of Maximum Likelihood Estimation (MLE). According to MLE approach, the number of good samples varies from 100 to 200 samples. Purposive proportional random sampling is used as the sampling technique for data collection in this research. The sort of questionnaire utilised in this study is the questionnaire with a Likert scale. The Likert scale, as defined by Sekaran and Bougie (2010) is used to determine how strongly the subject agrees or disagrees with assertions on a five-point scale. The score is given by the Likert scale in the form of ordinal data. According to Green (2017) must first be transformed to an interval scale by using Method of Successive Interval (MSI).

In analysis, we applied structural equation modelling (SEM) approach to explore the direct and indirect effects of self-efficacy and work environment on employee performance in PT Sarana Indoguna Lestari Surabaya. According to Nugraha and Jabeen (2020), data analysis technique using SEM is supposed to go through seven stages, firstly the development of theoretical models, secondly the development of path diagrams, thirdly the conversion of flowcharts into structural equations, and selecting an input matrix and model estimation, then analyzing the possibility of identification problems, and then evaluating of the Goodness of Fit criteria, and eventually interpreting and modifying the model.

\section{Result and Discussion}

According to Nugraha and Jabeen (2020), data analysis technique using SEM is supposed to go through seven stages, firstly the development of theoretical models, secondly the development of path diagrams, thirdly the conversion of flowcharts into structural equations, and selecting an input matrix and model estimation, then analyzing the possibility of identification problems, and then evaluating of the Goodness of Fit criteria, and eventually interpreting and modifying the model.

The Analysis of Moment Structure (AMOS) tool is used to process data using the Structural Equation Modeling (SEM) approach. The surveys were delivered directly to 150 people, with 135 of them having returned the questionnaires and this result for a $90 \%$ response rate. The data comes from the recapitulation of employee assessments at PT Sarana Indoguna Lestari in 2016-2020 which is contained in Table 2. Based on Table 2, there are four types of specific divisions, namely Gender, Age, division of Work and also work experience which are then divided into several sub-levels with a percentage assessment.

\subsection{Descriptive Analysis}

Table 3 shows the descriptive analysis outcome of respondents' responses for 
Table 2. Recapitulation of employee assessment in PT Sarana Indoguna Lestari.

\begin{tabular}{|c|c|c|c|}
\hline No & Respondent Overview & Total & Percentage \\
\hline \multicolumn{4}{|c|}{ 1. Gender } \\
\hline & - Male & 102 & 75.6 \\
\hline & - Female & 33 & 24.4 \\
\hline \multicolumn{4}{|c|}{ 2. Age } \\
\hline & - 17 - 20 years old & 3 & 2.2 \\
\hline & - 21 - 25 years old & 22 & 16.3 \\
\hline & - 26 - 30 years old & 41 & 30.4 \\
\hline & - 31 - 40 years old & 37 & 27.4 \\
\hline & - $\geq 40$ years old & 32 & 23.7 \\
\hline \multicolumn{4}{|c|}{ 3. Work Division } \\
\hline & - Butcher & 11 & 8.1 \\
\hline & - House Keeping & 4 & 3.0 \\
\hline & - Service & 7 & 5.2 \\
\hline & - Kitchen & 12 & 8.9 \\
\hline & - Cashier & 1 & 0.7 \\
\hline & - Security & 4 & 3.0 \\
\hline & - Receiver & 1 & 0.7 \\
\hline & - Office & 5 & 3.7 \\
\hline & - Delivery & 32 & 23.7 \\
\hline & - Department/Divison & 17 & 8.1 \\
\hline & - Warehouse & 14 & 12.6 \\
\hline & - Marketing & 15 & 10.4 \\
\hline & - Accounting & 4 & 11.1 \\
\hline & - Driver & 4 & 3.0 \\
\hline & - Food and Beverage & 1 & 3.0 \\
\hline & - IT & 3 & 0.7 \\
\hline \multicolumn{4}{|c|}{ 4. Working Experience } \\
\hline & - $<1$ year & 10 & 10 \\
\hline & - 1 - 3 years & 33 & 33 \\
\hline & - 3 - 5 years & 18 & 18 \\
\hline & - $\geq 40$ years old & 74 & 74 \\
\hline
\end{tabular}

Source: Questionnaire Data (2021).

Table 3. Recapitulation of respondents' answers.

\begin{tabular}{ccc}
\hline No & Variable & Average \\
\hline 1. & Self-efficacy & 4.11 \\
2. & Work Environment & 3.96 \\
3. & Motivation & 4.14 \\
4. & Performance & 4.51 \\
\hline
\end{tabular}

Source: Questionnaire Data (2021).

each variable. The average value of all the answers given by the respondents to the two exogenous research variables has a total score above the average of 3.40 - 
4.19 which means that the data is in the good category, and one of the endogenous variables is above the average of $3.40-4.19$ which means that the data is in the good category as well, and for another variable is above the average of 4.20 5.00 which means that the data is in very good category. The results of the self-efficacy variable are able to trigger employee motivation and performance. Confidence in self-ability has a positive impact on confidence to do work.

The results of the work environment variable indicate that the respondents have a perception that the conditions of the work environment such as the arrangement or coloring of the room can provide comfort that supports the performance of the employees. The results of the motivation variable indicate that the respondents have a perception that the equipment, supplies, main facilities, and supporting facilities owned by PT Sarana Indoguna Lestari Surabaya are safe and sufficient for employees. This condition has become the potential thing that motivates the employees in carrying out daily work activities.

\subsection{Quantitative Analysis}

The data processing technique used to carry out the quantitative analysis in this study utilizes the stages in the Structural Equation Modeling (SEM) analysis which is operated by using Analysis of Moment Structure (AMOS) 23 tool and further development is proposed to get the best research model. Quantitative analysis is needed to support the main data in the form of questionnaires to produce more relevant research results.

\subsection{Confirmatory Factor Analysis (CFA)}

Confirmatory Factor Analysis is also often referred to as a test of the validity of a theoretical construct (Masnita et al., 2019). The validity test in this study was assessed by looking at the standard loading factor derived from each indicator in the overall research model (Nugraha \& Jabeen, 2020). The indicator is declared valid if it has a standard loading factor value of more than 0.5 . The results of the confirmatory construct test for the variables of self-efficacy, work environment, motivation, and performance have standard loading factor values, namely Standardized Regression Weights that are above 0.5. Detail of standardized regression weights of all items in the model can be seen in Table 4.

\subsection{Structural Model Analysis and Outlier Data}

The causality relationship of several research variables tested in this study can be seen through the presentation of Figure 2. The number of samples used in this study are 135 respondents. And then, the evaluation of the normality of the data is done by looking at c.r multivariate value that results of 14.669 which is far above the range value of c.r 2.58. But then, this condition is certainly not to worry about because based on the central limit theorem, the existing sample data has been normally distributed due to the sample size that is more than 120 samples. The central limit theorem explains that a large sample will follow a normal 
Table 4. The value of construct reliability(CR).

\begin{tabular}{|c|c|c|c|c|c|c|}
\hline Variable & Item & Estimate & S.E & C.R & Prob. & $\begin{array}{c}\text { Standardized } \\
\text { Regression } \\
\text { Weights }\end{array}$ \\
\hline \multirow{8}{*}{ Self-efficacy } & S1 & 1.157 & 0.14 & 8.48 & $* * *$ & 0.782 \\
\hline & S2 & 0.928 & 0.13 & 6.93 & $* * *$ & 0.650 \\
\hline & S3 & 0.823 & 0.14 & 5.98 & $* * *$ & 0.548 \\
\hline & S4 & 1.025 & 0.13 & 8.02 & $* * *$ & 0.718 \\
\hline & S5 & 0.914 & 0.12 & 7.38 & $* * *$ & 0.665 \\
\hline & S6 & 0.937 & 0.13 & 7.35 & $* * *$ & 0.658 \\
\hline & S7 & 1.101 & 0.13 & 8.28 & $* * *$ & 0.757 \\
\hline & S8 & 1 & & & & 0.726 \\
\hline \multirow{7}{*}{$\begin{array}{l}\text { Work } \\
\text { Environment }\end{array}$} & LK1 & 1.495 & 0.24 & 6.36 & $* * *$ & 0.814 \\
\hline & LK2 & 1.556 & 0.24 & 6.50 & $* * *$ & 0.866 \\
\hline & LK3 & 1.443 & 0.23 & 6.31 & $* * *$ & 0.801 \\
\hline & LK4 & 1.356 & 0.23 & 6.03 & $* * *$ & 0.733 \\
\hline & LK5 & 1.240 & 0.21 & 5.79 & $* * *$ & 0.678 \\
\hline & LK6 & 1.066 & 0.21 & 5.18 & $* * *$ & 0.562 \\
\hline & LK7 & 1 & & & & 0.539 \\
\hline \multirow{12}{*}{$\begin{array}{c}\text { Employee } \\
\text { Performance }\end{array}$} & $\mathrm{K} 1$ & 1.341 & 0.19 & 7.00 & $* * *$ & 0.770 \\
\hline & $\mathrm{K} 2$ & 1.233 & 0.19 & 6.51 & $* * *$ & 0.702 \\
\hline & K3 & 1.172 & 0.18 & 6.51 & $* * *$ & 0.695 \\
\hline & $\mathrm{K} 4$ & 1.296 & 0.19 & 6.84 & $* * *$ & 0.746 \\
\hline & K5 & 1.277 & 0.19 & 6.89 & $* * *$ & 0.750 \\
\hline & K6 & 1.303 & 0.19 & 6.93 & $* * *$ & 0.758 \\
\hline & K7 & 1.352 & 0.19 & 7.14 & $* * *$ & 0.787 \\
\hline & K8 & 1.196 & 0.19 & 6.44 & $* * *$ & 0.687 \\
\hline & K9 & 1.088 & 0.18 & 6.00 & $* * *$ & 0.622 \\
\hline & K10 & 1.038 & 0.18 & 5.84 & $* * *$ & 0.594 \\
\hline & K11 & 1.217 & 0.18 & 6.69 & $* * *$ & 0.714 \\
\hline & K12 & 1 & & & & 0.593 \\
\hline \multirow{7}{*}{ Motivation } & M1 & 0.976 & 0.17 & 5.89 & $* * *$ & 0.622 \\
\hline & M2 & 1.097 & 0.17 & 6.44 & $* * *$ & 0.685 \\
\hline & M3 & 0993 & 0.16 & 6.12 & $* * *$ & 0.637 \\
\hline & M4 & 0.637 & 0.13 & 4.78 & $* * *$ & 0.500 \\
\hline & M5 & 0.970 & 0.16 & 6.17 & $* * *$ & 0.637 \\
\hline & M6 & 0.874 & 0.15 & 5.78 & $* * *$ & 0.584 \\
\hline & M7 & 0.928 & 0.16 & 5.80 & $* * *$ & 0.581 \\
\hline
\end{tabular}




\begin{tabular}{cccccc} 
Continued & \multicolumn{7}{l}{} \\
\hline M8 & 0.924 & 0.15 & 6.14 & $* * *$ & 0.611 \\
M9 & 0.921 & 0.16 & 5.90 & $* * *$ & 0.579 \\
M10 & 0.958 & 0.15 & 6.21 & $* * *$ & 0.606 \\
M11 & 0.862 & 0.14 & 5.97 & $* * *$ & 0.566 \\
M12 & 1 & & & & 0.638 \\
\hline
\end{tabular}

Source: AMOS Output.
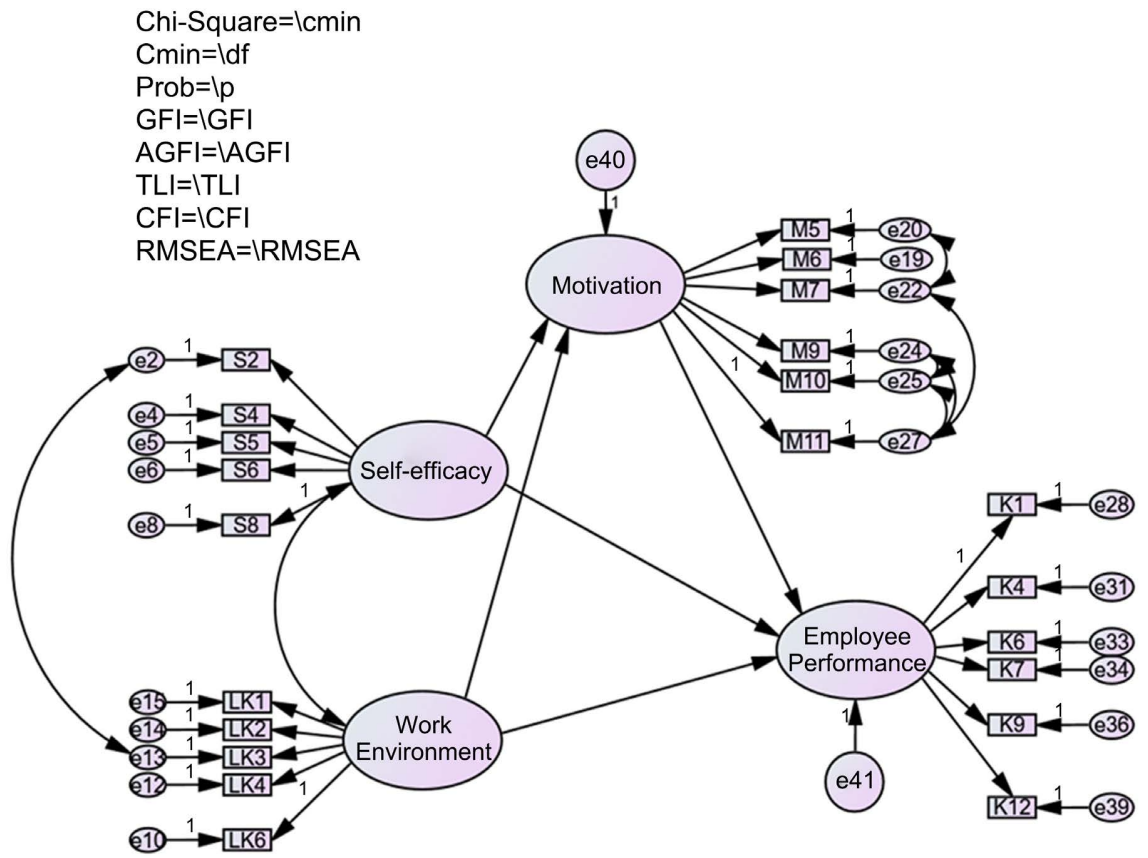

Figure 2. Fit model.

distribution even though the population from which the sample is obtained is not normally distributed (Hakimah et al., 2019).

Then, the outlier data can be detected by looking at the values at the Mahalonobis distance. The criterions used are based on the chi-square value of 39 in accordance with the number of indicators used with a significance level of $p \leq$ 0.001 , which is 72.05 . The highest value of Mahalanobis $d$-squares in the research data is 52.10 where this value is smaller than the value of 72.05 , so it can conclude that there are no outlier cases in the data.

\subsection{Model Fit Measurement}

All variables that make up the construct will be declared valid if the standard loading factor value is above 0.5 and the variance extract value is greater than 0.5 . If the $\mathrm{CR}$ value is greater than 0.70 then the data is reliable. The calculation results in Table 5 refer that the self-efficacy variable is reliable with its CR value (0.81), which is already above 0.7 . This is also applied for other variables in the construct of exogenous and endogenous variables, which are above 0.70 . 
Table 5. The value of construct reliability(CR).

\begin{tabular}{cc}
\hline Variabel & CR \\
\hline Self-efficacy & 0.81 \\
Work Environment & 0.87 \\
Motivation & 0.76 \\
Performance & 0.86 \\
\hline
\end{tabular}

\subsection{Model Feasibility Test}

The results of the model feasibility test in Table 6 shows that the absolute match value is the chi-square value of 225.633 which is smaller than 473.008 and the probability is 0.079 which is already above 0.05 . The value of RMSEA $=0.033 \leq$ 0.08 and $\mathrm{CMIN} / \mathrm{DF}=1.145 \leq 2.00$ which indicates that this value is a good index to accept the suitability of a model. Likewise, the value of GFI $=0.90=0.90$ and AGFI $=0.840 \leq 0.90$ which indicates that the model tested has a fairly good fit so that it can be accepted even though the AGFI value is still slightly below the required standard value but still into marginal fit. Based on the incremental fit values, the value of CFI $=0.977 \geq 0.90$, TLI $=0.973 \geq 0.90$, and $\mathrm{IFI}=0.978 \geq 0.90$ which are included in the good fit category because all of them have a value close to 1 (one). This indicates that the model has a good level of conformity and the model is acceptable, so it can conclude that the SEM model has met the model's feasibility test and can be used further to answer the research hypothesis.

\subsection{Model Feasibility Test}

After obtaining good results from the model feasibility test, then from the two structural equations obtained, the fit model can be formed from the AMOS Standardize regression weight output which is presented in Table 7.

Based on Table 5, the structural equation 1 explains that the variables of self-efficacy and work environment have effect on motivation. And then, the structural equation 2 defines that the variables of self-efficacy, work environment, and motivation have effect on performance.

\subsection{Hypothesis Testing}

Table 8 shows the results of hypotheses testing in this study. Hypothesis testing uses $t$-value with sig. 0.05 . The $t$-value in the AMOS tool is a critical value for the Regression Weigth Full Model that is already fit. If the critical ratio (c.r) $\geq 1.96$ or probability $(p) \leq 0.05$, then $\mathrm{H} 0$ is rejected and thus the alternative hypothesis (Ha) is accepted. It can be seen in Table 8 that the test results show that self-efficacy is not significant to performance but has a positive and significant effect on motivation. This finding shows that the high self-confidence of individual employees of PT Sarana Indoguna Lestari Surabaya on their abilities does not necessarily indicate their level of performance. On the other hand, the level of self-efficacy of PT Sarana Indoguna Lestari employees greatly affects their motivation to work. Furthermore, 
Table 6. Model fit test (Goodness of Fit Index).

\begin{tabular}{cccc}
\hline GOF Index & Cut of Value & Analysis Result & Model Evaluation \\
\hline $\mathrm{X}^{2}$ - Chi Square & $\leq 473.008$ & 225.633 & Good Fit \\
Probability & $\geq 0.05$ & 0.079 & Good Fit \\
RMSEA & $\leq 0.08$ & 0.033 & Good Fit \\
CMIN/DF & $\leq 2.00$ & 1.145 & Good Fit \\
GFI & $\geq 0.90$ & 0.90 & Good Fit \\
AGFI & $\geq 0.90$ & 0.840 & Marginal \\
CFI & $\geq 0.90$ & 0.977 & Good Fit \\
TLI & $\geq 0.90$ & 0.973 & Good Fit \\
IFI & $\geq 0.90$ & 0.978 & Good Fit \\
$\mathrm{X}^{2}$ - Chi Square & $\leq 473.008$ & 225.633 & Good Fit \\
Probability & $\geq 0.05$ & 0.079 & Good Fit \\
\hline
\end{tabular}

Source: AMOS Output.

Table 7. Model fit test (goodness of fit index).

\begin{tabular}{cccc}
\hline & \multicolumn{2}{c}{ Direction } & Model Evaluation \\
\hline Motivation & $<---$ & Self-efficacy & 0.434 \\
Motivation & $<---$ & Work environment & 0.426 \\
Performance & $<---$ & Self-efficacy & 0.114 \\
Performance & $<---$ & Work environment & -0.423 \\
Performance & $<---$ & Motivation & 1.070 \\
\hline
\end{tabular}

Source: AMOS Output.

Table 8. Results of hypothesis testing.

\begin{tabular}{|c|c|c|c|}
\hline Hypothesis & Statement & Parameter & Conclusion \\
\hline $\mathrm{H} 1$ & $\begin{array}{l}\text { Self-efficacy significantly has positive } \\
\text { impact on performance. }\end{array}$ & $\begin{array}{c}\text { Estimate } 0.128 \\
\text { S.E } 0.197 \\
\text { C.R } 0.650 \\
\text { Prob. } 0.516\end{array}$ & Rejected \\
\hline $\mathrm{H} 2$ & $\begin{array}{l}\text { Work environment significantly has } \\
\text { positive impact on performance. }\end{array}$ & $\begin{array}{c}\text { Estimate }-0.566 \\
\text { S.E } 0.244 \\
\text { C.R }-2.319 \\
\text { Prob. } 0.020\end{array}$ & Accepted \\
\hline H3 & $\begin{array}{c}\text { Self-efficacy has significant impact on } \\
\text { motivation. }\end{array}$ & $\begin{array}{c}\text { Estimate } 0.289 \\
\text { S.E } 0.095 \\
\text { C.R } 3.028 \\
\text { Prob. } 0.002\end{array}$ & Accepted \\
\hline $\mathrm{H} 4$ & $\begin{array}{l}\text { Work environment has significant } \\
\text { impact on motivation. }\end{array}$ & $\begin{array}{c}\text { Estimate } 0.338 \\
\text { S.E } 0.120 \\
\text { C.R } 2.812 \\
\text { Prob. } 0.005\end{array}$ & Accepted \\
\hline
\end{tabular}


Continued

\begin{tabular}{|c|c|c|c|}
\hline H5 & $\begin{array}{l}\text { Motivation has significant impact on } \\
\text { performance. }\end{array}$ & $\begin{array}{c}\text { Estimate } 1.803 \\
\text { S.E } 0.574 \\
\text { C.R } 3.140 \\
\text { Prob. } 0.002\end{array}$ & Accepted \\
\hline H6 & $\begin{array}{l}\text { Self-efficacy has significant impact on } \\
\text { performance by existence of motivation. }\end{array}$ & $\begin{array}{l}\text { Direct Effect } 0.114 \\
\text { Indirect Effect } 0.465\end{array}$ & Accepted \\
\hline $\mathrm{H7}$ & $\begin{array}{l}\text { Work environment significantly has } \\
\text { positive impact on performance by } \\
\text { existence of motivation. }\end{array}$ & $\begin{array}{l}\text { Direct Effect }-0.423 \\
\text { Indirect Effect } 0.455\end{array}$ & Accepted \\
\hline
\end{tabular}

Source: AMOS Output.

the test results show that although the work environment has a negative impact on performance, it significantly affects the motivation of PT Sarana Indoguna Lestari employees. Furthermore, the results also show that work motivation has a positive and significant relationship to the performance of PT Sarana Indoguna Lestari employees.

Based on the test results on the indirect effect of the self-efficacy variable on performance, it shows that the motivational variable mediates the relationship between self-efficacy and performance. This shows that the employees of PT Sarana Indoguna Lestari Surabaya need motivation from the leadership/management of the company. This finding illustrates that the better the application of self-efficacy, the better the effect on employee motivation and indirectly encourages employees to more optimally complete their work. Furthermore, the findings also show that the motivational variable mediates the relationship between the work environment and employee performance. This shows that in order to achieve maximum performance, employees of PT Sarana Indoguna Lestari Surabaya need a good work environment and need motivation from their superiors or company managers to improve their performance. Fulfillment of elements of the physical and non-physical work environment has a positive impact and motivates employees to improve performance. The provision of a good work environment, such as the provision of work facilities and equipment according to work standards, is an indirect form of motivation that can increase employee motivation and has the potential to improve employee performance.

\section{Conclusion}

Our results discovered that self-efficacy did not have direct effect on performance; otherwise work environment positively has direct effect on performance. These findings indicated that employee performance was influenced by condition work environment and clearly was not impacted by their self-efficacy. In other words, comfortability of work environment potentially stimulates employee performance in PT Sarana Indoguna Lestari Surabaya. Based on these findings we suggest to firm policymakers to create comfortable work environ- 
ment for employees. Next, we also found that self-efficacy and work environment have direct effects on motivation, meanwhile motivation directly has positive effect on performance. These findings show that both self-efficacy and work environment have a positive impact and stimulate employees' motivation which then potentially encourage improving performance of employees. These hypotheses are appropriate with our findings on indirect effect analysis, where we found that both self-efficacy and work environment have an indirect effect on employee performance when motivation is determined as the mediating variable among those variables.

Based on the results, we suggest several recommendations that expected will help improve employees' performance. First, we suggest the policymakers or top management in company provide support toward all elements of motivation which are directly nor indirectly associated with employee performance. Second, considering that work environment an important element that has direct and indirect impact on employees' motivation, we recommend company to improve employees' working environment in order to stimulate increased employee performance. Furthermore, our study is expected to provide contribution as an alternative reference that is useful for assisting further research processes, especially research related to employee performance in companies engaged in food and beverage distribution in Indonesia.

\section{Conflicts of Interest}

The authors declare no conflicts of interest regarding the publication of this paper.

\section{References}

Adeoye, A. O. (2019). Compensation Management and Employees' Motivation in the Insurance Sector: Evidence from Nigeria. Facta Universitatis, Series: Economics and Organization, 16, 31-47. https://doi.org/10.22190/FUEO1901031A

Andrianto, T., \& Siringoringo, J. P. (2020). The Influence of Work Environment and Motivation on Employee Performance in Wood Factory. International Journal of Economics, Business and Accounting Research (IJEBAR), 4, 191-196. https://doi.org/10.29040/ijebar.v4i01.948

Bandura, A. (1982). Self-Efficacy Mechanism in Human Agency. American Psychologist, 37, 122-147. https://doi.org/10.1037/0003-066X.37.2.122

Bandura, A. (2012). On the Functional Properties of Perceived Self-Efficacy Revisited. Journal of Management, 38, 9-44. https://doi.org/10.1177/0149206311410606

Bayramoğlu, G., Şahin, M., DeVellis, B. M., Youssef, C. M., Luthans, F., Youssef, C. M., Hodges, T. D., Malik, A., \& Lunenburg, F. C. (2013). Self-Efficacy in the Workplace: Implications for Motivation and Performance. Journal of Management, 14, 1-6.

Cherian, J., \& Jacob, J. (2013). Impact of Self Efficacy on Motivation and Performance of Employees. International Journal of Business and Management, 8, 80-88. https://doi.org/10.5539/ijbm.v8n14p80

Coutinho, S. (2008). Self-Efficacy, Metacognition, \& Performance. North American Journal of Psychology, 10, 165-172. 
Cui, W., Cao, G., Park, J. H., Ouyang, Q., \& Zhu, Y. (2013). Influence of Indoor Air Temperature on Human Thermal Comfort, Motivation and Performance. Building and Environment, 68, 114-122. https://doi.org/10.1016/j.buildenv.2013.06.012

Day, R., \& Allen, T. D. (2004). The Relationship between Career Motivation and Self-Efficacy with Protégé Career Success. Journal of Vocational Behavior, 64, 72-91. https://doi.org/10.1016/S0001-8791(03)00036-8

Diamantidis, A. D., \& Chatzoglou, P. (2019). Factors Affecting Employee Performance: An Empirical Approach. International Journal of Productivity and Performance Management, 68, 171-193. https://doi.org/10.1108/IJPPM-01-2018-0012

Efendi, R., Rifa'i, M. N., Bahrun, K., Milla, H., \& Suharmi, S. (2020). The Mediation of Work Motivation on the Effects of Work Discipline and Compensation on Performance Batik SME's Employees in Yogyakarta City, Indonesia. International Journal of Multicultural and Multireligious Understanding, 7, 689-703.

Green, B. (2017). The Method of Successive Intervals. In Scaling (pp. 122-128). Routledge. https://doi.org/10.4324/9781315128948-13

Hair, J. F., Ringle, C. M., \& Sarstedt, M. (2013). Partial Least Squares Structural Equation Modeling: Rigorous Applications, Better Results and Higher Acceptance. Long Range Planning, 46, 1-12. https://doi.org/10.1016/j.lrp.2013.01.001

Hakimah, Y., Hildayanti, S. K., \& Nugraha, A. T. (2019). Influence of Economic Indicators on Supply Chain: Evidence from Indonesian Fishing Industry. International Journal of Supply Chain Management, 8, 854-863.

Hasyim, F. (2018). The Effects of Self-Efficacy on Motivation of Reading English Academic Text. Ahmad Dahlan Journal of English Studies, 5, 25-34.

https://doi.org/10.26555/adjes.v5i1.8597

Hughes, A. M., Zajac, S., Woods, A. L., \& Salas, E. (2020). The Role of Work Environment in Training Sustainment: A Meta-Analysis. Human Factors: The Journal of the Human Factors and Ergonomics Society, 62, 166-183. https://doi.org/10.1177/0018720819845988

Jayaweera, T. (2015). Impact of Work Environmental Factors on Job Performance, Mediating Role of Work Motivation: A Study of Hotel Sector in England. International Journal of Business and Management, 10, 271-278. https://doi.org/10.5539/ijbm.v10n3p271

Khan, M. I. (2012). The Impact of Training and Motivation on Performance of Employees. Business Review, 7, 84-95. https://doi.org/10.54784/1990-6587.1205

Kreitner, R., Kinicki, A., \& Fagan, P. D. (2001). Videos to Accompany Organizational Behavior, 5/e. Irwin/McGraw-Hill.

Kurtessis, J. N., Eisenberger, R., Ford, M. T., Buffardi, L. C., Stewart, K. A., \& Adis, C. S. (2017). Perceived Organizational Support: A Meta-Analytic Evaluation of Organizational Support Theory. Journal of Management, 43, 1854-1884.

https://doi.org/10.1177/0149206315575554

Li, C. (2020). Self-Efficacy Theory. In Routledge Handbook of Adapted Physical Education (pp. 313-325). Routledge. https://doi.org/10.4324/9780429052675-24

Lunenburg, F. C. (2011). Self-Efficacy in the Workplace: Implications for Motivation and Performance. International Journal of Management, Business, and Administration, 14, $1-6$.

Maarleveld, M., Volker, L., \& van der Voordt, T. J. M. (2009). Measuring Employee Satisfaction in New Offices-The WODI Toolkit. Journal of Facilities Management, 7, 181-197. https://doi.org/10.1108/14725960910971469 
Malik, M. I., Ahmad, A., Gomez, S. F., \& Ali, M. (2011). A Study of Work Environment and Employees' Performance in Pakistan. African Journal of Business Management, 5, 13227-13232. https://doi.org/10.5897/AJBM11.1502

Masnita, Y., Yakub, A., Nugraha, A. T., \& Riorini, S. V. (2019). Influence of Government Support, Technology Support and Islamic Banking Awareness on Islamic Banking Choice in Indonesia with Moderating Role of Religiosity. International Journal of Innovation, Creativity and Change, 6, 46-66.

Mathis, R. L., \& Jackson, J. H. (2006). Human Resource Management. Thomson/South-Western.

Mone, E. M., \& London, M. (2018). Employee Engagement through Effective Performance Management. Routledge. https://doi.org/10.4324/9781315626529

Morrow, P. (1993). The Theory and Measurement of Work Commitment. JAI Press.

Narasuci, W., Setiawan, M., \& Noermijati, N. (2018). Effect of Work Environment on Lecturer Performance Mediated by Work Motivation and Job Satisfaction. Jurnal Aplikasi Manajemen, 16, 645-653. https://doi.org/10.21776/ub.jam.2018.016.04.11

Nguyen, P. D., Dang, C. X., \& Nguyen, L. D. (2015). Would Better Earning, Work Environment, and Promotion Opportunities Increase Employee Performance? An Investigation in State and Other Sectors in Vietnam. Public Organization Review, 15, 565-579. https://doi.org/10.1007/s11115-014-0289-4

Nugraha, A. T., \& Jabeen, R. (2020). Education Quality Management by Encouraging Wellbeing and Discouraging Inequality among Society. International Journal of Innovation, Creativity and Change, 10, 444-458.

Olusola, O. (2011). Intinsic Motivation, Job Satisfaction and Self-Efficacy as Predictors of Job Performance of Industrial Workers in Ijebu Zone of Ogun State. Journal of International Social Research, 4, 569-577.

Pajares, F., \& Miller, M. D. (1994). Role of Self-Efficacy and Self-Concept Beliefs in Mathematical Problem Solving: A Path Analysis. Journal of Educational Psychology, 86, 193-203. https://doi.org/10.1037/0022-0663.86.2.193

Palvalin, M. (2019). What Matters for Knowledge Work Productivity? Employee Relations, 41, 209-227. https://doi.org/10.1108/ER-04-2017-0091

Palvalin, M., Lönnqvist, A., \& Vuolle, M. (2013). Analysing the Impacts of ICT on Knowledge Work Productivity. Journal of Knowledge Management, 17, 545-557. https://doi.org/10.1108/JKM-03-2013-0113

Pangastuti, P. A. D., Sukirno, \& Efendi, R. (2020). The Effect of Work Motivation and Compensation on Employee Performance. International Journal of Multicultural and Multireligious Understanding, 7, 292-299.

Redifer, J. L., Bae, C. L., \& Zhao, Q. (2021). Self-Efficacy and Performance Feedback: Impacts on Cognitive Load during Creative Thinking. Learning and Instruction, 71, Article ID: 101395. https://doi.org/10.1016/j.learninstruc.2020.101395

Robbins, S. P., \& Coulter, M. (2012). Management (11th ed.). Pearson Education.

Schmidt, A. M., \& DeShon, R. P. (2010). The Moderating Effects of Performance Ambiguity on the Relationship between Self-Efficacy and Performance. Journal of Applied Psychology, 95, 572-581. https://doi.org/10.1037/a0018289

Sekaran, U., \& Bougie, R. (2010). Research Method for Business: A Skill Building Approach (5th ed.). John Wiley \& Sons Inc.

Shahzadi, I., Javed, A., Pirzada, S. S., Nasreen, S., \& Khanam, F. (2014). Impact of Employee Motivation on Employee Performance. European Journal of Business and Man- 
agement, 6, 159-166.

Tierney, P., \& Farmer, S. M. (2011). Creative Self-Efficacy Development and Creative Performance over Time. Journal of Applied Psychology, 96, 277-293. https://doi.org/10.1037/a0020952

Van Dijk, D., \& Kluger, A. N. (2011). Task Type as a Moderator of Positive/Negative Feedback Effects on Motivation and Performance: A Regulatory Focus Perspective. Journal of Organizational Behavior, 32, 1084-1105. https://doi.org/10.1002/job.725

Vancouver, J. B., Gullekson, N. L., Morse, B. J., \& Warren, M. A. (2014). Finding a Between-Person Negative Effect of Self-Efficacy on Performance: Not Just a Within-Person Effect Anymore. Human Performance, 27, 243-261.

https://doi.org/10.1080/08959285.2014.913593

Widiyanti, M., Sadalia, I., \& Nugraha, A. T. (2020). Integrating Fiscal Matters with Environmental Sustainability in ASEAN Countries: Role of Fiscal Deficit, Interest Rate and Stock Exchange Index. Journal of Security and Sustainability Issues, 10, 349-359. https://doi.org/10.9770/jssi.2020.10.Oct(28)

Zameer, H., Ali, S., Nisar, W., \& Amir, M. (2014). The Impact of the Motivation on the Employee's Performance in Beverage Industry of Pakistan. International Journal of Academic Research in Accounting, Finance and Management Sciences, 4, 293-298.

https://doi.org/10.6007/IJARAFMS/v4-i1/630 